\title{
PENINGKATKAN SIKAP EMPATI MELALUI BIMBINGAN KELOMPOK BERBANTUAN TEKNIK PROBLEM SOLVING PADA SISWA KELAS X.A.V.1 SMK NEGERI 1 JIWAN KABUPATEN MADIUN
}

\author{
Nuril Annissa Ekayanti *) \\ Vitalis Djarot Sumarwoto **)
}

Secara psikologis, setiap manusia pada dasarnya memerlukan sikap empati dalam hidupnya. Sikap empati lebih dibutuhkan seseorang (siswa) dalam upaya menumbuhkembangkan rasa kepedulian yang mendalam kepada sesama manusia. Para psikologi perkembangan menegaskan bahwa sesungguhnya terdapat dua komponen empati, yaitu: reaksi emosi kepada orang lain, yang lebih berkembang dalam usia kehidupan anak; dan reaksi kognitif, yang menentukan sampai sejauh mana siswa mampu mampu memandang sesuatu sesuatu dari sudut pandang atau perspektif orang lain.

Realitas di sekolah menunjukkan bahwa tidak semua individu (siswa) mampu mengembangkan sikap empati yang dimilikinya. Peristiwa ini dialami oleh siswa kelas X.AV.1 SMK Negeri 1 Jiwan Kabupaten Madiun. Terdapat 10 siswa yang mengalami sikap empati yang rendah, sehingga apabila perilaku tersebut dibiarkan maka akan menghambat perkembangan siswa selanjutnya. Salah satu solusi untuk meningkatkan empati siswa yang rendah tersebut adalah melalui bimbingan kelompok berbantuan teknik problem solving.

Tujuan penelitian ini adalah untuk mengetahui seberapa efektif layanan bimbingan kelompok berbantuan teknik problem solving dapat meningkatkan sikap empati siswa kelas X AV 1 SMK Negeri 1 Jiwan Kabupaten Madiun. Sampel penelitian ini sebanyak 10 siswa kelas X AV 1SMK Negeri 1 Jiwan Kabupaten Madiun, yang terindikasi memiliki tingkat sikap empati rendah. Penetapan sampel penelitian menggunakan teknik diagnosis dengan cara menyebar angket awal.

Penelitian ditempuh dengan menggunakan metode eksperimen, dengan desain One-Group Pretest-Posttest Design. Bentuk eksperimen yang dilakukan dengan memberikan treatment sebanyak empat kali selama dua minggu, dengan rincian pertemuan dua kali dalam seminggu dengan alokasi waktu 120 menit/tatap muka. Analisis data menggunakatn teknik uji $t$-score.

Hasil analisis data menunjukkan bahwa $r_{\text {hitung }}>r_{\text {tabel }}$ (hipotesis penelitian diterima). Jadi dapat disimpulkan bahwa melalui layanan bimbingan kelompok berbantuan teknik problem solving dapat meningkatkan sikap empati siswa kelas $X$ AV 1 SMK Negeri 1 Jiwan Kabupaten Madiun. Oleh sebab itu disarankan bahwa sekolah dapat memanfaatkan layanan bimbingan kelompok berbantuan problem solving sebagai teknik yang pantas dikembangkan untuk membina kepribadian individu.

Kata Kunci: Sikap Empati, Bimbingan Kelompok Berbantuan Teknik Problem Solving 


\section{A. Pendahuluan}

Dewasa ini permasalahan yang berkaitan dengan aspek kemanusiaan atau kepedulian terhadap sesama manusia dirasakan semakin berkurang. Hal ini terjadi seiring dengan derasnya arus modernisasi, yang hampir melanda seluruh pelosok di wilayah di dunia ini. Akibatnya kehidupan berkembang cenderung menjadi sangat individualis, kurang tergerak hatinya dalam ikut merasakan penderitaan sesama, budaya kepedulian sangat rendah. Pernyataan tersebut pada dasarnya memberi petunjuk kurang adanya sikap empati pada diri seseorang (individu).

Secara umum, empati diartikan sebagai bagian dari kehidupan psikis, yang merupakan ikut tergeraknya hati dan pikiran seseorang terhadap situasi dan kondisi psikis orang lain. Dalam arti ini, maka perasaan empati dapat dilakukan asalkan dalam diri sesorang itu memiliki kemauan untuk ikut merasakan segala sesuatu yang dirasakan orang lain (sesama), kapan saja dan dimana saja berada. Jadi jelas bahwa sikap empati sangat diperlukan dalam kehidupan sehari-hari, karena perasaan empati dapat menumbuhkan rasa kepedulian yang mendalam terhadap sesama. Konsekuensinya, bahwa manusia yang kurang atau bahkan tidak memiliki sikap empati akan bersikap acuh tak acuk atau cenderung berperilaku semaunya, tidak peduli dengan keadaan sesamanya, dan tidak memiliki kepekaan terhadap kehidupan sesamannya. Sikap demikian tersebut yang saat ini dimiliki oleh sebagain siswa kelas X.AV.1 SMK Negeri 1 Jiwan Kabupaten Madiun.

Berdasarkan situasi riil di atas, maka peneliti bekerja sama dengan konselor sekolah mengadakan diagnosis, pada minggu ketiga bulan September tahun 2015. Diagnosis awal dilakukan dengan cara menyebar angket awal kepada siswa kelas X.A.V.1 SMK Negeri 1 Jiwan Madiun yang berjumlah 35 orang siswa. Tujuan penyebaran angket tersebut adalah untuk mengidentifikasi masalah tentang sikap empati pada siswa tersebut. Hasil diagnosis menunjukkan bahwa terdapat sebanyak 10 dari 35 siswa kelas X.A.V.1 SMK memiliki sikap empati yang rendah. Sikap empati siswa yang rendah tersebut dalam realitasnya memiliki bentuk yang bervariasi, seperti: lebih mementingkan diri sendiri, kurang peduli terhadap penderitaan temannya. Penyebabnya antara lain adalah $70 \%$ dari 10 siswa yang bermasalah itu berasal dari keluarga yang kurang haromnis, 20\% berasal dari keluarga yang tidak utuh, dan $10 \%$ siswa berasal dari keluarga yang menjadi ibu terlalu muda. Kenyataan diatas perlu segera dicarikan solusinya agar tidak menghambat perkembangannya.

Salah satu solusi yang diyakini efektif adalah dengan memberikan program layanan bimbingan kelompok berbantuan prolem solving. Teknik dijadikan solusi karena memeiliki kelebihan dapat meningkatkan sikap empati siswa. Harapannya setelah diberikan treatmen dengan frekuensi sebanyak empat kali peremuan/sekali dalam seminggu, pada bulan Desember 2015 maka dapat mengubah perilaku siswa menjadi: lebih baik, ramah, menumbuhkan kerjasama, sosialitas siswa 
berkembang. Dengan kata lain diharapkan siswa mampu melepaskan sifat ego sektoralnya, dan lebih membuka diri terhadap perilaku orang lain di sekitarnya.

Menurut Winkel (dalam Vitalis DS., 2003) sikap harus dipandang sebagai aktivitas psikis untuk menerima atau menolak obyek atas dasar penilaian apakah obyek yang dihadapi itu berharga atau tidak berharga. Pernyataan ini memberi petunjuk bahwa jika siswa menilai bahwa obyek yang dihadapi itu berharga (baik bagi perkembangannya) maka siswa akan bersikap positif, dan menerima dengan sepenuh hati. Sebaliknya, jika siswa menilai bahwa obyek tidak berharga (tidak baik bagi perkembangannya) maka siswa akan bersikap negatif, sehingga menolak obyek yang dihadapinya. Sikap pada hakikatnya merupakan suatu predisposisi atau kesiap-siagaan individu (siswa) dalam merespon stimulus-stimulus dari luar dirinya. Sikap dapat dipelajari atau dikondisikan, sikap adalah proyeksi dari perilaku. Bagian integral dari kepribadian seseorang (siswa) yang dapat diamati melalui perilakunya. Menurut Kohut (dalam Taufik, 2012) empati diartikan sebagai suatu proses di mana seseorang berpikir mengenai kondisi orang lain yang seakan-akan dia berada pada posisi orang lain itu.

Berdasarkan beberapa pendapat di atas maka dapat ditarik suatu pelajaran bahwa yang dimaksud dengan sikap empati adalah kecenderungan subyek (siswa) untuk menerima layanan bimbingan kelompok berbantuan problem solving untuk meningkatkan sikap empati siswa atas dasar penilaian bahwa melalui kegiatan tersebut adalah berharga bagi pembinaan kepribadian dirinya. Program layanan bimbingan kelompok dengan teknik problem solving oleh siswa dinilai positif, maka siswa menerimanya sebagai hal yang berharga bagi kehidupannya.

Layanan bimbingan kelompok merupakan suatu cara pemberian bantuan (bimbingan) kepada individu (siswa) melalui kegiatan kelompok, yang membahas tentang topik-topik umum menjadi kepentingan bersama anggota kelompok (Tohhirin, 2007). Masalah-masalah dalam bimbingan kelompok dibahas melalui suasana kelompok secara intens dan konstruktif, diikuti oleh semua anggota kelompok dibawah bimbingan pemimpin kelompok. Sedang Supriatna (2011) menjelaskan bahwa layanan bimbingan kelompok dimaksudkan untuk mencegah berkembangnya masalah atau kesulitan pada diri konseli (siswa). Menurut Dewa Ketut Sukardi (2008) hakikat layanan bimbingan kelompok adalah sebagai bantuan yang memungkinkan sejumlah siswa secara bersama-sama memperoleh berbagai bahan dari nara sumber tertentu menunjang kehidupannya sehari-hari.

Bertolak dari beberapa pendapat ahli di atas, maka menurut peneliti yang dimaksud dengan layanan bimbingan kelompok adalah bantuan yang disampaikan oleh konselor yang profesional kepada konseli tentang berbagai informasi yang bermanfaat bagi kepentingan individu atau kelompok, yang dipecahkan secara bersama-sama dalam kelompok agar terhindar dari masalah-masalah dalam hidupnya. Pada dasarnya fungsi layanan bimbingan kelompok adalah pemberian 
informasi, pengembangan dan preventf serta kuratif. Isi layanan bimbingan kelompok berupa penyampaian informasi yang berkenaan dengan masalahmasalah pendidikan, pekerjaan, pribadi dan masalah sosial yang tidak disajikan dalam bentuk pelajaran, dan diselesaikan melalui pemecahan masalah (problem solving).

Menurut Bahri \& Zain (2013) problem solving merupakan suatu metode pemecahan masalah, yang melibatkan metode berpikir, dan metode-metode lain yang dimulai dengan mencari, menganalisis data sampai menarik kesimpulan. Melalu teknik problem solving siswa menghadapi dan memecahkan masalah secara terampil, sehingga dapat diaplikasikan pada pemecahan dalam kehidupan sehari-hari, baik di sekolah, kehidupan keluarga, dan dalam bermasyarakat, serta ketika siswa bekerja kelak. Melalui kegiatan kelompok dengan teknik problem solving siswa memperoleh kemampuan yang sangat bermakna bagi kehidupan yang akan datang. Layanan bimbingan kelompok dengan teknik problem solving merupakan salah satu teknik layanan kelompok dengan melibatkan unsur kognitif (berpikir) untuk pemecahan masalah yang timbul dalam kehidupannya. Tujuan yang ingin dicapai melalui layanan bimbingan kelompok adalah meningkatkan sikap empati melalui suasana kelompok.

\section{B. Kajian Pustaka}

\section{Sikap Empati}

\section{a. Pengertian Sikap}

Sarlito (2010) berpendapat bahwa sikap adalah istilah yang mencerminkan rasa senang, tidak senang, atau perasaan biasa-biasa saja (netral) dari seseorang terhadap sesuatu. "Sesuatu" itu bisa benda, kejadian, situasi, orang-orang atau kelompok. Kalau yang timbul terhadap sesuatu itu adalah perasaan senang, sikap positif, sedangkan kalau perasaan tak senang, sikap negatif. Kalau tidak timbul perasaan apa-apa, berarti sikapnya netral.

King (2012), berpendapat bahwa sikap adalah berbagai pendapat dan keyakinan kita mengenai orang lain, objek, atau gagasan sederhananya, bagaimana kita merasakan berbagai hal.

Winkel (dalam Vitalis, 2003) menegaskan bahwa sikap adalam kecenderungan psikis untuk menerima atau menolak suatu obyek atas dasar penilaian bahwa obyek tersebut berharga (baik karena membantu mengembangkan hidupnya) atau tidak berharga (tidak baik karena menghambat hidupnya).

Atas dasar beberapa pendapat tersebut maka dapat dirumuskan bahwa hakikat sikap adalah kesiap-siagaan (pre disposition) seseorang untuk menerima atau menolak obyek (sikap) atas dasar suatu penilaian bahwa obyek yang dihadapi itu sebagai sesuatu yang 
berharga (mengembangkan dirinya) atau tidak berharga (yang dapat menghambat perkembangan dirinya). Oleh karena itu di dalam sikap mengandung aspek kognitif (menilai) dan afektif (menerima atau menolak) yang sama-sama memiliki peran.

b. Pengertian Empati

Para psikologi perkembangan menegaskan bahwa sesungguhnya ada dua komponen empati: reaksi emosi kepada orang lain - yang normalnya berkembang dalam enam tahun pertama dalam kehidupan anak - dan reaksi kognitif yang menentukan sampai sejauh mana anak-anak ketika sudah lebih besar mampu memandang sesuatu dari sudut pandang atau perspektif orang lain (Shapiro, 2003). Sedang Roger (dalam Taufik, 2012) menawarkan dua konsepsi. Pertama, dia menulis empati adalah melihat kerangka berpikir internal orang lain secara akurat. Kedua, dalam memahami orang lain tersebut individu seolah-olah masuk dalam diri orang lain sehingga bisa merasakan dan mengalami sebagaimana yang dirasakan dan dialami oleh orang lain itu, tetapi tanpa kehilangan identitas dirinya sendiri. Disisi lain istilah empati dikemukakan oleh Ten Boom (2008) yaitu kemampuan merasakan, mengalami, dan mengambil bagian dalam batin orang lain (Chaterina, 2013).

\section{Bimbingan Kelompok dengan Teknik Problem Solving}

a. Bimbingan Kelompok

Winkel dan Sri Hastuti (2006) mendefinisikan bimbingan kelompok adalah bantuan yang diberikan oleh konselor yang berwenang kepada sejumlah individu secara bersama-sama untuk memperoleh pemecahan masalah individu.

Sukardi (2008) berpendapat bahwa inti layanan bimbingan kelompok adalah suatu proses bantuan yang memungkinkan siswa secara bersama-sama, melalui dinamika kelompok, memperoleh bahan dari nara sumber tertentu (dari pembimbing/konselor) yang berguna untuk menunjang kehidupannya sehari-hari baik individu maupun sebagai pelajar, anggota keluarga dan masyarakat serta untuk mempertimbangkan pengambilan keputusan/tindakan tertentu.

Agus Mulyadi (2004) mengartikan layanan bimbingan kelompok adalah proses membantu individu (siswa) dalam memecahkan masalah-masalah atau problem-problem yang dihadapinya dengan secara bersama-sama dalam kelompok.

Bertolak dari uraian di atas, maka yang dimaksud dengan layanan bimbingan kelompok itu pada dasarnya adalah bantuan 
pemecahan masalah-masalah individu (siswa) yang dilaksanakan secara kelompok (baik dalam kelompok yang besar atau kecil).

b. Teknik Problem Solving

Ngalimun (2014) mengemukakan bahwa teknik problem solving adalah cara-cara yang ditempuh oleh individu untuk mencari, menemukan dan menyelesaikan (menemukan pola, aturan, atau logaritma). Sintaknya adalah: sajikan permasalahan yang memenuhi kriteria, siswa berkelompok atau individual mengidentifikasi pola atau aturan yang disajikan, siswa mengidentifikasi, mengeksplorasi, menginvestigasi, menduga, dan akhirnya menemukan solusi.

Bahri \& Zain (2013) mengemukakan bahwa teknik problem solving merupakan suatu metode berpikir dalam upaya menemukan dan menyelesaikan masalah-masalah yang timbul, sampai menarik suatu kesimpulan.

Bertolak dari beberapa pengertian di atas peneliti berpendapat bahwa hakikat teknik problem solving suatu cara atau langkahlangkah yang ditempuh oleh seseorang untuk mencari, menemukan dan menganalisis suatu masalah sehingga diperoleh jalan keluarnya.

\section{Metodologi Penelitian}

\section{Metode dan Desain Penelitian}

Metode yang ditempuh dalam penelitian ini adalah eksperimen. Penggunaan metode eksperimen dalam penelitian ini dipandang cukup representatif, karena sesuai dengan pendapat Sugiyono (2013) yang menyatakan bahwa metode penelitian eksperimen adalah suatu teknik dalam penelitian, yang digunakan untuk mencari pengaruh perlakuan tertentu terhadap yang lain dalam kondisi yang terkendalikan.

Desain penelitian menggunakan one group pre-test dan post-test desain. Dalam desain ini observasi dilakukan pada siswa kelas X AV 1 yang diberikan sebanyak dua kali, yaitu dilakukan sebelum eksperimen dan sesudah eksperimen. Observasi yang dilakukan sebelum diberi treatment (pre-test), dan sesudah diberi treatment (post-test). Langkah selanjutnya membandingkan kedua skor hasil angket tersebut.

\section{Populasi dan Sampel penelitian}

Populasi adalah wilayah generalisasi yang terdiri atas individu yang mempunyai kualitas dan karakteristik tertentu yang ditetapkan oleh peneliti untuk dipelajari dan ditarik kesimpulannya Sugiyono, (2013)

Atas dasar pendapat Sugiyono tersebut maka populasi penelitian ini ditetapkan siswa kelas X AV 1 SMK Negeri 1 Jiwan Kabupaten Madiun yang berjumlah 23 siswa. 
Sampel penelitian ditetapkan sebanyak 10 dari 23 orang siswa kelas X AV.1 SMK Negeri 1 Jiwan Kabupaten Madiun, yang memiliki sikap empati cukup rendah. Secara metodologis penetapan jumlah anggota sampel penelitian telah memenuhi syarat. Hal ini didukung oleh pendapat Sugiyono (2013) yang menyatakan bahwa sampel adalah bagian dari jumlah dan karakteristik yang dimiliki oleh populasi penelitian.

Penetapan anggota sampel penelitian menggunakan teknik purposive sampling. Menurut Sutrisno Hadi (2015) teknik purposive sampling dapat dipertanggungjawabkan, dengan pertimbangan bahwa pemilihan sekelompok subjek didasarkan atas ciri-ciri atau sifat-sifat populasi yang sudah diketahui sebelumnya. Ciri tertentu tersebut adalah bahwa para anggota sampel penelitian adalah berasal dari kelas dan sekolah yang sama, serta usia siswa relatif sama. Sedangkan sifat tertentu adalah bahwa anggota sampel berada pada masalah yang sama, yaitu mempunyai empati yang rendah.

\section{Teknik Pengumpulan Data}

Teknik pengumpulan data dalam penelitian ini menggunakan angket. Teknik angket digunakan untuk mengungkap data tentang sikap empati siswa antara sebelum dan setelah diberi layanan bimbingan kelompok berbantuan teknik problem solving. Instrumen yang disediakan dalam penelitian ini adalah satu seri angket, yang disebarkan kepada responden dua kali, yaitu sebelum dan sesudah diberi layanan bimbingan kelompok berbantuan problem solving. Penggunaan angket dalam penelitian ini secara metodologis telah memenuhi persyaratan. Hal ini didukung oleh pendapat Sugiyono (2013:199) yang menyatakan bahwa "Angket adalah teknik pengumpulan data yang dilakukan dengan cara memberi seperangkat pertanyaan atau pernyataan tertulis kepada responden untuk dijawabnya". Oleh karena itu penggunaan angket dalam penelitian ini telah memenuhi persyaratan metodologis.

Angket penelitian disusun sendiri oleh peneliti dalam bentuk pilihan ganda, dengan empat alternatif jawaban : a. Selalu, b. Sering, c) Kadangkadang, d) Tidak Pernah. Jumlah item yang disediakan adalah 30 item untuk setiap angket.

Pemberian skor hasil isian angket pada penelitian ini mengacu pada skala Likert, mengingat yang diukur melalui angket adalah aspek: sikap, pendapat, dan persepsi seseorang atau sekelompok orang tentang fenomena sosial (Sugiono). Distribusi skor untuk jawaban angket seperti dapat dilihat pada tabel di bawah ini 
Tabel.1.Distribusi Skor Untuk Jawaban Angket

\begin{tabular}{|c|c|c|c|c|}
\hline Jawaban & Selalu & Sering & Kadang & $\begin{array}{c}\text { Tidak } \\
\text { Pernah }\end{array}$ \\
\hline Skor Positif (+) & 4 & 3 & 2 & 1 \\
\hline Skor Negatif (-) & 1 & 2 & 3 & 4 \\
\hline
\end{tabular}

Ketentuan pemberian skor angket adalah sebagai berikut :

1. Jawaban selalu: (positif) diberi skor: 4, dan (negatif) diberi 1.

2. Jawaban sering: (positif) diberi skor: 3, dan (negatif) diberi skor: 2 .

3. Jawaban kadang-kadang: (positif) diberi skor: 2, dan (negatif) diberi skor: 3

4. Jawaban tidak pernah: (positif) diberi skor: 1, dan (negatif) diberi skor: 4.

\section{Analisis Data Penelitian}

Analisis data penelitian menggunakan teknik validitas isi (content validity), dengan pertimbangan bahwa instrumen yang digunakan untuk mengungkap data penelitian disusun untuk mengetahui pelaksanaan program yang direncanakan. Untuk menguji validitas isi, dapat dibantu dengan menggunakan kisi-kisi intrumen. Kisi-kisi instrumen memuat item-item variabel penelitian, yang dijabarkan melalui indikator item yang berfungsi sebagai tolak ukur pernyataan angket. Atas dasar kisi-kisi angket maka pengujian validitas item dapat dilakukan dengan mudah dan sistematis.

Langkah selanjutnya menghitung korelasi skor hasil isian angket sikap empati antara sebelum dan sesudah diberi treatment problem soving dengan rumus bangun korelasi Product Moment Pearson. Rumus bangun korelasi Product Moment adalah sebnagai berikut:

$$
r_{x y}=\frac{N \sum X Y-\left(\sum X\right)\left(\sum Y\right)}{\left.\sqrt{\left\{N \sum X^{2}-\left(\sum X\right)^{2}\right\} N \sum Y^{2}-\left(\sum Y\right)^{2}}\right\}}
$$


(Suharsimi Suharsimi, 2013)

Keterangan :

$\mathrm{r}_{\mathrm{xy}}=$ Koefisien korelasi antara $\mathrm{X}$ dan $\mathrm{Y}$

$\sum X=$ Jumlah skor item

$\sum Y=$ Jumlah skor total

$\mathrm{n}$ = Banyaknya subyek

Untuk mengetahui tingkat kestabilan alat ukur dilakukan uji reliabilitas dengan menggunakan rumus alpha. Adapun rumus alpha adalah sebagai berikut :

$$
r_{11}=\left\{\frac{k}{k-1}\right\}\left\{1-\frac{\sum \sigma_{b}^{2}}{\sigma^{2}{ }_{1}}\right\}
$$

( Arikunto, 2013)

Keterangan :

$r_{11}=$ Reliabilitas Instrumen

$k \quad=$ Banyaknya butir pernyataan

$\sum \sigma_{b}^{2}=$ Jumlah varians butir

$\sigma^{2}{ }_{1}=$ Varians total

Sedangkan untuk rumus varians butir dan varians total adalah

sebagai berikut :

$$
\mathrm{ab}=\frac{\sum X^{2}-\left(\sum X\right)^{2}}{\mathrm{n}}
$$

Varians total :

$$
\text { at }=\frac{\sum Y^{2}-\left(\sum Y\right)^{2}}{\mathrm{n}}
$$

Keterangan :

$\mathrm{ab}:$ Varians butir

at : Varians total

$\mathrm{X}$ : Skor butir

Y : Skor total

$\mathrm{n}$ : Jumlah subyek 
Untuk menguji hipotesis dari penelitian efektifitas layanan bimbingan kelompok teknik Problem Solving untuk meningkatkan empati siswa, peneliti menggunakan uji statistik dengan uji $t$-score. Formula $t$-score pada dasarnya sama dengan $z$-score, yang tidak lagi berurusan dengan angka kasar, tetapi distribusi perbedaan mean. Penerapan rumus $t$-score adalah sebagai berikut: :

$$
t=\frac{M x-M y}{S D_{b M}}
$$

(Sutrisno Hadi, 2015)

Keterangan :

$=$ Taraf Kepercayaan

Mx = Mean dari kelompok sebelum mendapatkan treatment

My = Mean dari kelompok setelah mendapatkan treatment

SDbm $=$ Standart kesalahan perbedaan mean

\section{Hasil Penelitian}

\section{Deskripsi Data}

Berdasarkan hasil perhitungan data pada lampiran 8, yang dihitung dengan bantuan SPSS v 16 dan Microsoft Excel, dapat dideskripsikan sebagai berikut :

a. Deskripsi Data Empati Sebelum Diberikan Treatment Bimbingan Kelompok Dengan Teknik Problem Solving

Data hasil isian angket, dengan $\mathrm{N}=10$, rentang skor: $60-108$. diperoleh perhitungan: Mean $=78,80$, Median $=69,00$, Modus $=60$, dan standar deviasi $(\mathrm{SD})=1,888$, skor tertinggi $=108$, dan skor terendah $=60$. Mengingat data di atas akan dilaporkan dalam bentuk grafik histogram, maka perlu menghitung range (R) dan lebar kelas (i). $\mathrm{R}$ adalah selisih antara batas nyata atas dengan batas nyata bawah $(108,5-59,5=49)$. Ditentukan lebar kelas $(\mathrm{i})=5$, maka $\mathrm{R}$ untuk skor distribusi frekuensi bergolong $=(49+1): 5=10$. 
Tabel 2. Distribusi Frekuensi Data Empati Sebelum Diberikan Treatment Bimbingan Kelompok Dengan Teknik Problem solving (Posttest)

\begin{tabular}{|c|c|}
\hline Interval Nilai (i) & Frekuensi (f) \\
\hline $105-109$ & 2 \\
\hline $100-104$ & 0 \\
\hline $95-99$ & 1 \\
\hline $90-94$ & 0 \\
\hline $85-89$ & 1 \\
\hline $80-84$ & 0 \\
\hline $75-79$ & 0 \\
\hline $70-74$ & 1 \\
\hline $65-69$ & 3 \\
\hline $60-64$ & 2 \\
\hline$\sum$ & 10 \\
\hline
\end{tabular}

Berdasarkan hasil distribusi nilai diatas dapat dibuat grafik sebagai:

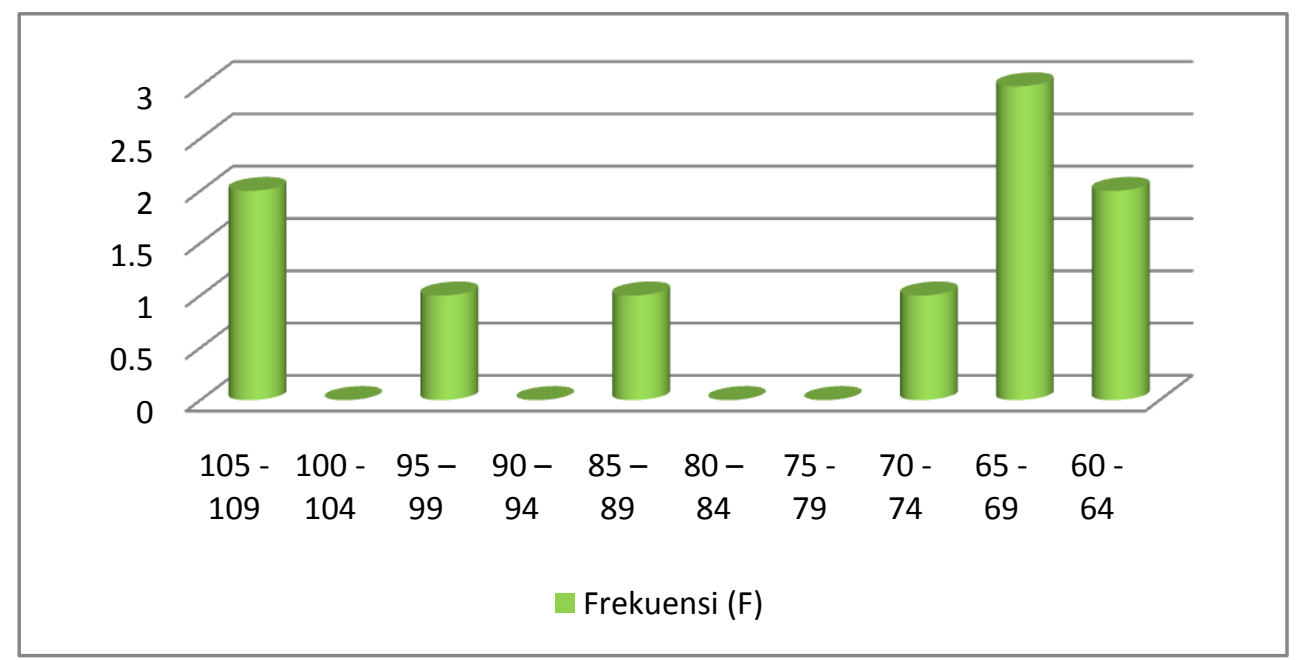

Gambar 1. Empati Sebelum Diberikan Treatment Bimbingan Kelompok Dengan Teknik Problem Solving (Pretest) 
Berdasarkan hasil analisis pada tabel diatas adalah tingkat empati sebelum mendapatkan layanan bimbingan kelompok dengan teknik problem solving berada dalam kriteria sangat tinggi, tinggi, sedang, rendah dan sangat rendah, dan hasil skor empati siswa pada pretest lebih banyak pada tingkat yang rendah yaitu $60 \%$ pada indikator pertama, kedua $40 \%$ dan $40 \%$ juga pada indikator ketiga. Secara keseluruhan kriteria rendah mendapatkan presentase tertinggi dibanding kriteria lainnya. Hal ini menunjukkan bahwa cukup rendah empati siswa pada hasil pretest atau sebelum mendapat layanan bimbingan kelompok dengan teknik problem solving

b. Deskripsi Data Empati Setelah Diberikan Treatment Layanan Bimbingan Kelompok Dengan Teknik Problem Solving (Posttest)

Berdasarkan pada lampiran 8 yang dihitung dengan bantuan SPSS v 16 dan Microsoft Excel, dapat dideskripsikan sebagai berikut :

Data diperoleh dari data angket empati sesudah diberi bimbingan kelompok dengan teknik problem solving (posttest) yang berjumlah 30 item, dengan rentang skor angket antara 68103. Mengingat sampel $(\mathrm{N})=10$, maka diperoleh data sebagai berikut: mean $=65,90$, median $=68,00$ modus $=46$ dan standar deviasi $=2,059$ nilai tertinggi $=103$, nilai terendah $=41$. (hasil selengkapnya dapat dilihat pada lampiran 8)

Mengingat bahwa data tersebut akan dilaporkan dalam bentuk diagram batang, maka perlu disediakan tabulasi data. Langkah-langkahnya adalah sebagai berikut: menghitung rentang kelas (R) dan lebar kelas (i). Rentang kelas $(\mathrm{R})=$ batas atas nyata skor tertinggi dikurangi batas nyata skor terendah $(103,5-40,5=$ 63). Ditentukan interval kelas (i) $=7$, maka $\mathrm{R}$ untuk skor distribusi frekuensi $(63: 7)=9$ 
Tabel 3 Distribusi Frekuensi Data Empati Sesudah Diberikan Treatment Bimbingan Kelompok Dengan Teknik Problem Solving (Posttest)

\begin{tabular}{|c|c|}
\hline Interval Nilai (I) & Frekuensi (f) \\
\hline $97-103$ & 1 \\
\hline $90-96$ & 0 \\
\hline $83-89$ & 0 \\
\hline $76-82$ & 4 \\
\hline $69-75$ & 0 \\
\hline $62-68$ & 0 \\
\hline $55-61$ & 1 \\
\hline $48-54$ & 1 \\
\hline $41-47$ & 3 \\
\hline Jumlah & $\mathbf{1 0}$ \\
\hline
\end{tabular}

Berdasarkan hasil distribusi nilai diatas dapat dibuat grafik berikut

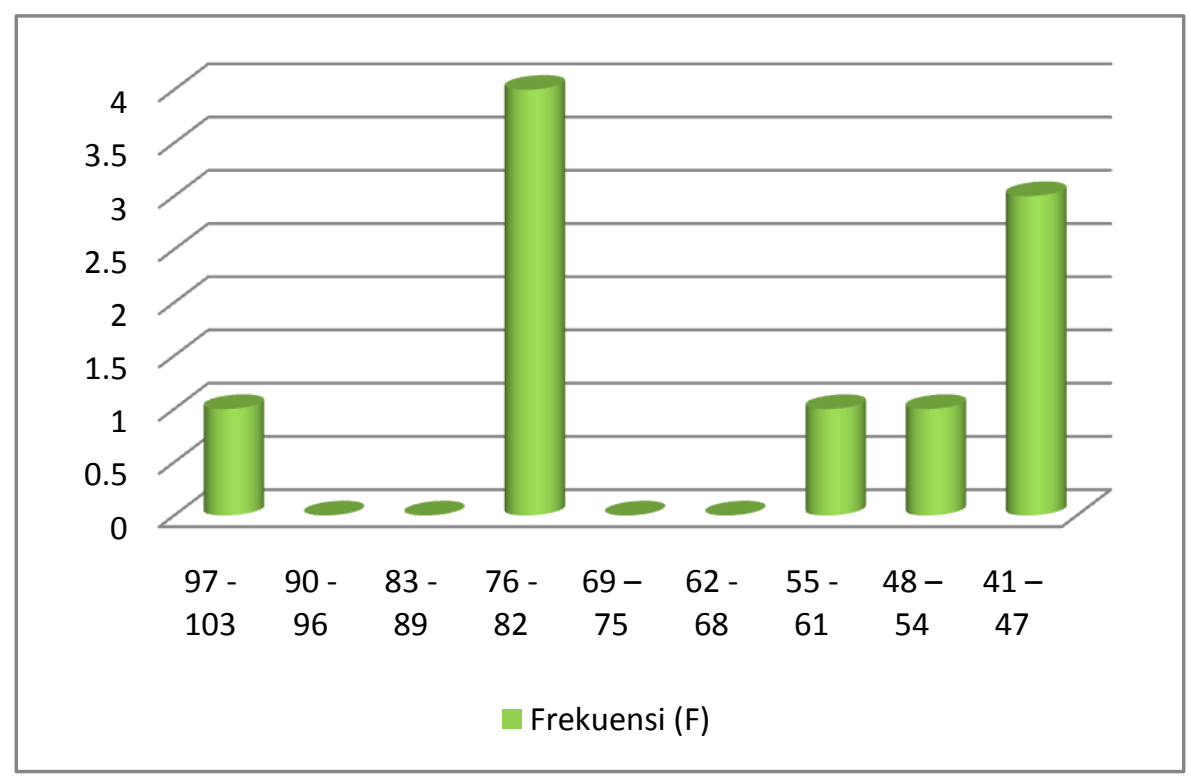

Gambar 2. Empati Sesudah Diberikan Treatment Bimbingan Kelompok Dengan Teknik Problem Solving (Posttest) 


\section{E. Hasil Analisis Data}

\section{Pengujian Hipotesis}

Hasil analisis data penelitian menunjukkan bahwa harga t-hitung ( $t$ score $)=9,211$. Setelah dikonsultasikan dengan harga t-tabel, dengan $\mathrm{N}=$ 10 dan d.b $=9(\mathrm{~N}-1)$ maka diketahui bahwa harga t-tabel $=2,262$ $\mathrm{TS}=5 \%$. Jadi harga t-hitung lebih besar dibandingkan dengan harga ttabel $(9,211>2,262 / \mathrm{TS}=5 \%)$ atau signifikan.

\section{Simpulan Hasil Pengujian Hipotesis}

Berdasarkan dari hasil analisis penelitian maka dapat disimpulkan bahwa hipotesis penelitian yang berbunyi: "Ada peningkatan sikap empati melalui bimbingan kelompok dengan teknik problem solving untuk siswa kelas X AV.1 SMK Negeri 1 Jiwan Kabupaten Madiun”, dinyatakan harus diterima.

\section{F. Simpulan dan Saran}

\section{Simpulan}

Berdasarkan hasil penelitian maka dapat disimpulkan bahwa bimbingan kelompok dengan berbantuan teknik problem solving dapat meningkatkan sikap empati siswa kelas X.A.V.1 SMK Negeri 1 Jiwan Kabupaten Madiun.

\section{Saran}

Bertolak dari simpulan tersebut di atas maka dapat dikemukakan saran sebagai berikut:

a. Pihak sekolah dapat memanfaatkan hasil penelitian sebagai bahan masukan bagi sekolah untuk meningkatkan sikap empati siswa, sehingga siswa mampu menghadapi tugas perkembangan dengan baik

a. Guru dan konselor skeolah

Guru dan konselor sekolah dapat memanfaatkan hasil penelitian ini sebagai masukan dalam upaya menyusun program bimbingan secara terpadu dengan menekankan sikap empati dalam layanan bimbingan individu atau kelompok bagi siswa di skeolah. 


\section{DAFTAR PUSTAKA}

Arikunto, Suharsimi. 2013. Prosedur Penellitian Suatu Pendekatan Praktik. Jakarta : Rineka Cipta

Djamarah, S.B dan Zain, Aswan. 2010. Strategi Belajar Mengajar Edisi Revisi. Jakarta : Rineka Cipta.

Hadi, Sutrisna. 2015. Statistik. Yogyakarta : Pustaka Pelajar.

King, L.A. 2012. Psikologi Umum Sebuah Pandangan Apresiatif. Jakarta : Salemba Humanika.

Ngalimun. 2012. Strategi dan Model Pembelajaran. Yogyakarta: Aswaja Presindo

Sarwono, S.W. 2010. Pengantar Psikologi Umum. Jakarta : PT Rajagrafindo Persada.

Shapiro, L. E. 1997. Mengajarkan Emotional Intelligence pada Anak. Terjemahan oleh Kantjono, A. T. (2003). Jakarta: Gramedia Pustaka Utama.

Sukardi, D. K dan Kusmawati, Nila. 2008. Proses Bimbingan dan Konseling Disekolah. Jakarta : Rineka Cipta.

Sugiyono. 2013. Metode Penelitian Pendidikan Pendekatan Kuantitatif, kualitatif dan $R \& D$. Bandung : CV. Alfabeta.

Taufik. 2012. Empati Pendekatan Psikologi Sosial. Jakarta: Rajagrafindo Persada.

Vitalis DS., Perilaku Manusia. Madiun: IKIP PGRI Madiun. 